\title{
Socio Economic Scenario of the Farming Community Living in Climate Sensitive Indian Sundarbans
}

\author{
Suchandra Dutta ${ }^{1}$, Sanjit Maiti ${ }^{2}$, Sanchita Garai ${ }^{2}$, Mukesh Bhakat $^{2}$ and \\ Subhashis Mandal ${ }^{3}$ \\ ${ }^{1}$ Bidhan Chandra Krishi Viswavidyalaya, Mohanpur, Nadia 741252, West Bengal, India \\ ${ }^{2}$ ICAR-National Dairy Research Institute, Karnal 132001, Haryana, India \\ ${ }^{3}$ ICAR-Central Soil Salinity Research Institute, Regional Research Station, Canning Town, \\ South 24 Parganas 743329, West Bengal, India \\ *Corresponding author
}

\section{Keywords}

Socio economic status, Climate change, Farming Community, Indian Sundarbans, Agriculture, Livestock rearing, Fishing

\section{Article Info}

Accepted:

22 January 2019

Available Online:

10 February 2019

\section{A B S T R A C T}

The Indian Sundarbans is a coastal delta and major climate hotspot located in the state of West Bengal. The delta faces significant climatic challenges. The residents mainly depend on agriculture, livestock rearing and fishing. They face challenges of poverty, marginalization and an acute struggle against geo-climatic events. The present study was conducted to know the socio economic status of the farming community under the given resources viz. demographic, physical, economic, natural and social. A total of 120 mixed farmers were randomly selected from 10 villages of 5 blocks of Indian Sundarbans for the purpose of the study. The independent variables were calculated using frequency, percentage, mean and standard deviation methods. Based on the primary data which were collected by personal interview, it was found that the respondents were marginal farmers having average operational land holding of 0.41 hectare. The cropping intensity was 155.10 percent which means the area is under two crops in a year. They practiced diversified cropping pattern in an agriculture year in upland, medium land and lowland area.53.83 percentage of land holding was supplied with irrigation annually. The herd composed of cattle, sheep and goat. The productivity of both indigenous and cross bred cattle was $1.53 \mathrm{~kg} /$ day and $2.90 \mathrm{~kg} /$ day respectively which were very low. 53.96 percent of the average income was earned from crop cultivation, 15.67 percent from livestock and 29.96 percent from fisheries.42.5 percent household having credit accessibility and majority did not get credit from any sources. All the respondents had experienced extreme climatic events during last 10 years. It was found that 31.67 percent of the family respondent had migrated to cities in search of employment. 81.67 percent respondents were having extension contact. Out of which 86.73 percent having extension contact for crop cultivation, 70.41 percent having extension contact for livestock rearing and 45.92 percent having extension contact for fishing. This study provides a reasonable coverage of key socio-economic dimensions that will help the policy maker while formulating any strategies for the farming community of the climate sensitive Indian Sunderbans. 


\section{Introduction}

The Sunderbans, a delta of the rivers the Ganga, the Brahmaputra and the Meghna is located in West Bengal state of India and neighboring country of Bangladesh, is the largest delta of the world. It is famous for its uniqueness in floral and faunal strength, detritus ecosystem, intricate coastline, innumerable islands, criss cross distributaries and inhabitants of a very typical culture is declared as the 'World Heritage Site' by UNESCO in 1984 and Global Biosphere Reserve in 1989. The Government of India endorsed the deltaic complex as a Biosphere Reserve to ensure protection to this unique gene pool of the planet Earth that spreads over 102 islands. The Indian region is demarcated by the river Hooghly on the west, the Bay of Bengal on the south, the IchamatiKalindi-Raimongal rivers on the east and the Dampier-Hodges line on the north. The climate of this coastal region is hot humid with three distinct seasons, viz. winter, summer and monsoon. Based on various studies around the globe, it is now widely accepted among scientists that the values of the some of the basic climatic parameters, namely the air temperature, air pressure, relative humidity and precipitation, are changing at an alarming rate in the worldwide scale, especially since the last few decades (IPCC, 2013).

In recent years there is growing scientific evidence (IPCC, 2015; Hazra et al., 2010; Danda, 2011; CSE, 2012; Government of West Bengal, 2010) that the Sundarbans are facing climate changes in the last four decades. These are profoundly affecting the lands, homes and livelihoods of the local communities, especially those living in the island pockets (Danda, 2011). These changes manifest themselves in changes to the temperature and rainfall (e.g. longer summers, shorter winters, erratic rainfall), as well as sea level rises, coastal erosion and an increasing frequency of cyclonic events (Danda, 2011). The torturous interplay of climatic changes along with changing market forces and globalization has led to growing livelihood uncertainties in the Sundarbans. The inhabited area of Indian Sundarbans comprises 54 islands with a dense population of about five million people (Government of India, 2011) spread over 19 administrative blocks. They face challenges of poverty, marginalization and an acute struggle against geo-climatic events. The nature of farming is different in Sundarban as segments of land are not conjoined, which makes the fair distribution of water a problem. Paucity of sweet water in the region poses a major problem for irrigation (Pakrashi, 2016). Thus the Sundarbans, a coastal, underdeveloped area, is one of the most sensitive victims of climate change in India.

Socio-economic scenarios constitute an important tool for exploring the long-term consequences of climate change and available response options. The present study was conducted to know the socio economic status of the farming community under the given resources viz. demographic, physical, economic, natural and social. The study investigates some of the most challenging and important questions about climate change confronting the farming community.

\section{Materials and Methods}

\section{Study area}

The purposively selected Indian Sundarbans comprises of 19 Community Development blocks of North and South 24-Parganas districts of West Bengal (Figure 1). Out of 19 blocks, 5 blocks namely, Canning-I, Basanti, Kultali, Namkhana and Kakdwip were randomly selected. Subsequently, 2 villages from each block were selected randomly. 
Thus, the present study was confined to 10 villages.

\section{Selection of respondents}

From each village 12 farmers who were mixed farmers involved in the activity of the growing of crops as well as the raising of livestock and fishing activities were selected, randomly, as respondents for this study. Hence, a total of 120 respondents were selected for the purpose of accomplishing the objective of the study. Data were collected by personal interview method at the door step of the farmers and/or grazing ground and/or their field of crop production with the help of pretested structured interview schedule.

\section{Results and Discussion}

Socioeconomic status is a composite measure of an individual's economic and sociological standing. It is a complex assessment measured in a variety of ways that account for a person's work experience and economic and social position in relation to others, based on income, education, and occupation. In the present study, it has been measured based on five resources namely, demographic, physical, economic, natural and social.

\section{Demographic resources}

A cursory look at the data in the Table 1 revealed that majority of household head was male. The average age of the respondents of Indian Sunderban was 51.87 year which is quite mature as regard to farm experience. The average age of family member was 36.26 years which illustrate that the younger generation is higher in the family composition. The average formal education of the respondents was 5.58 years of schooling which means they were having primary level of education. The average family education status was 5.64 years of schooling which shows poor level of literacy.

\section{Physical resources}

The variables present in Table 2 shows the access of physical resources of the farmers. Operational land holding was considered as the total land area held under a single management for the purpose of cultivation. The respondents of Indian Sunderban were marginal farmers having average operational land holding of 0.41 hectare.

The cropping intensity of the studied area was 155.10 percent which means that more than 50 percent of the area is under two crops in a year. The cropping pattern of the surveyed household highlights a diversified cropping pattern followed in an agriculture year in upland, medium land and lowland area.53.83 percentage of land holding was supplied with irrigation annually. The herd composed of cattle (both indigenous and cross bred), sheep and goat. Most indigenous cattle are nondescript and some are upgraded with Gir and Sahiwal. The productivity of both indigenous and cross bred were $1.53 \mathrm{~kg} / \mathrm{day}$ and 2.90 $\mathrm{kg} /$ day respectively which were very low. Average meat of sheep and goat were $5.36 \mathrm{~kg}$ and $4.38 \mathrm{~kg}$ respectively.

\section{Financial or economic resources}

From Table 3, it is evident that the average annual income of the marginal farmers was Rs.44,775. Figure 2 depicts that 54 percent of the average income was earned from crop cultivation, 16 percent from livestock and 30 percent from fisheries.

Table 3 clearly depicts that 42.5 percent household were having credit accessibility and majority did not get credit from any sources. Figure 3 shows that the sources utilized for credit accessibility were commercial banks, cooperatives banks, money lender, friendly loan and neighbours. Majority access credit is from money lenders. 


\section{Natural resources}

Table 4 vividly portrays that all the respondents of the studied area had experienced extreme climatic events during last 10 years. Figure 4 shows that majority of the respondents had witnessed storm and cyclone. Climate change is altering weather and climate patterns and affecting the reliability of traditional climate knowledge. Climate information can help farmers better manage risk, making the most of favorable climatic conditions while protecting their livelihoods from extreme events. Table 4 shows that all the farmers used to get the readily available and reliable climatic information. Also, Table 4 portrays the various sources of climatic information such as radio, television, newspaper, village gram panchayat and fellow farmers. It also highlights that the farmers mainly seeks information regarding weather forecast, temperature, and rainfall.

\section{Social resources}

It was found that 31.67 percent of the family respondent had migrated to cities in search of employment. The average number of days migrated by the members of family was around 287 days. The migrated family members generally returned back to their home during the crop season and engaged themselves in farming. Most of their places of migration were Kolkata, Chennai, Gujarat, and Kerala. The types of job they perform were tailoring, factory labour, factory office bearer, goldsmith, labour supervisor, medical representative, plumber, shopkeeper, etc. in the urban area. Table 5 shows the social migration of the respondents. Social Participation measure the involvement of the respondents in formal or informal social organization as the members or as office bearers, this variable was being used. Table 5 shows that all the respondents were either member or office bearer in any formal or informal social organization. To measure the degree of exposure of the farming community to various extension workers/agencies for getting proper information regarding crop cultivation, livestock rearing, fisheries and other aspect of agriculture as well as the adaptation strategies to meet with the climatic challenges. It was noted that speedy and effective technology transfer and information dissemination is possible through regular extension contact. Table 5 depicts that 81.67 percent respondents having extension contact. Out of which 86.73 percent were having extension contact for crop cultivation, 70.41 percent were having extension contact for livestock rearing and 45.92 percent were having extension contact for fishing. In order to measure the assistance received from the external community organization an attempt was made to study this variable. This variable explores the type and number of organization and their assistance to the farming community. Table 5 vividly describes that 70.83 percent of the respondent received assistance in terms of financial support, critical input, demonstration and training from the external agencies. The external agencies that render service were Central Soil Salinity Research Institute, Regional Research Station, Canning Town, Central Institute of Brackish Aquaculture-Kakdwip Research Center, Ramakrishna Ashram Krishi Vigyan KendraNimpith, National Agricultural Innovation Project and National Initiative on Climate Resilient Agriculture. Farmers learn many things from their own experiments and their fellow farmers adapt these successful experiments for the development of their own farm. Results presented in Table 5 represents that 67.5 percent of the respondents used to get information from their fellow farmers regarding vermicomposting, brackish aquaculture, land shaping techniques, ornamental fishing, bee-keeping, etc. 
Table.1 Demographic resource profile of the farmers $(n=120)$

\begin{tabular}{|l|c|c|}
\hline Gender & Frequency & Percentage \\
\hline $\begin{array}{l}\text { Male } \\
\text { Female }\end{array}$ & 103 & 85.83 \\
\hline Average age of the household head (Years) & 17 & 14.17 \\
\hline & MEAN & Standard Deviation \\
\hline Average age of the adult family members & 51.87 & 10.78 \\
\hline Average score of educational status of the household head & 36.26 & 6.35 \\
\hline $\begin{array}{l}\text { Average score of family educational status of the sampled } \\
\text { household }\end{array}$ & 5.58 & 4.08 \\
\hline
\end{tabular}

Table.2 Physical resources profile of the farmers $(n=120)$

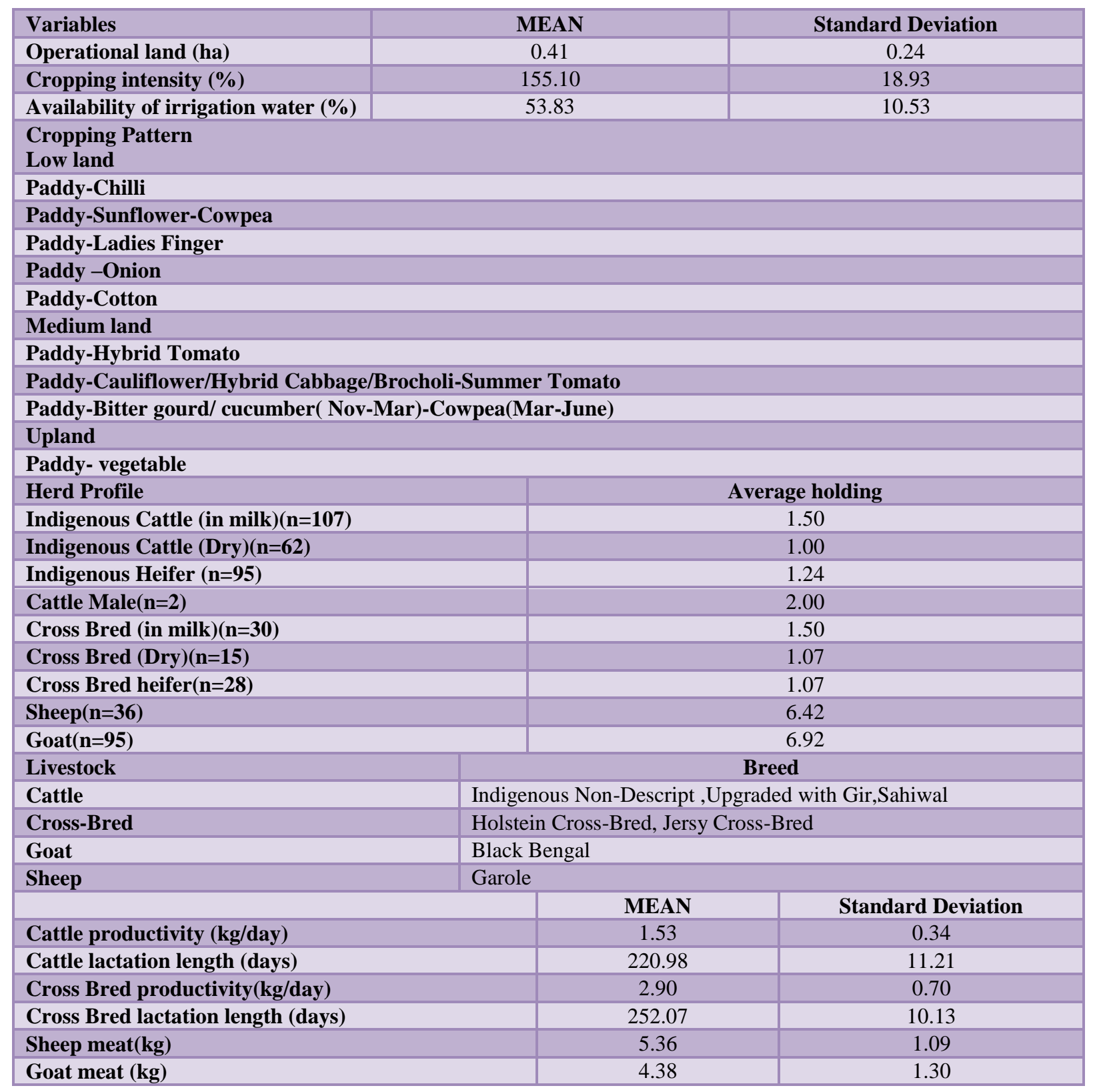


Table.3 Financial or economic resources profile of the farmers $(n=120)$

\begin{tabular}{|c|c|c|}
\hline \multicolumn{2}{|c|}{} & \\
\hline Variables & MEAN & Standard Deviation \\
\hline Average Income (Rs.) & 44,775 & 42720.21 \\
\hline Credit Accessibility & Frequency & Percentage \\
\hline$\bullet \begin{array}{l}\text { Household having credit } \\
\text { accessibility }\end{array}$ & 51 & 42.50 \\
\hline $\begin{array}{l}\text { Household do not have credit } \\
\text { accessibility }\end{array}$ & 69 & 57.50 \\
\hline
\end{tabular}

Table.4 Natural resources profile of the farmers $(n=120)$

\begin{tabular}{|c|c|c|}
\hline Variables & Frequency & Percentage \\
\hline Experiencedextreme climate events & 120 & 100 \\
\hline Having Climatic Information & 120 & 100 \\
\hline Sourcesof Climatic Information & \multirow[t]{2}{*}{120} & \multirow[t]{2}{*}{100} \\
\hline $\begin{array}{l}\text { Radio, Television, Newspaper, Village } \\
\text { gram panchayat and Fellow farmers }\end{array}$ & & \\
\hline Types of Climatic Information & \multirow[t]{2}{*}{120} & \multirow[t]{2}{*}{100} \\
\hline $\begin{array}{l}\text { Weather Forecast on Temperature, } \\
\text { Rainfall, Cyclone }\end{array}$ & & \\
\hline
\end{tabular}

Table.5 Social resources profile of the farmers

\begin{tabular}{|l|c|c|}
\hline \multicolumn{1}{|c|}{ Variables } & Frequency & Percentage \\
\hline Households having social migration & 38 & 31.67 \\
\hline $\begin{array}{l}\text { Households having no social } \\
\text { migration }\end{array}$ & 82 & 68.33 \\
\hline $\begin{array}{l}\text { Social participation of family } \\
\text { member }\end{array}$ & 120 & 100 \\
\hline Having extension contact & 98 & 81.67 \\
\hline $\begin{array}{l}\text { No extension contact } \\
\text { Having extension contact for crop } \\
\text { cultivation }\end{array}$ & 22 & 18.33 \\
\hline $\begin{array}{l}\text { Having extension contact for } \\
\text { livestock rearing }\end{array}$ & 85 & 86.73 \\
\hline Having extension contact for fishing & 69 & 70.41 \\
\hline $\begin{array}{l}\text { Assistance received from External } \\
\text { Agency }\end{array}$ & 85 & 45.92 \\
\hline $\begin{array}{l}\text { No Assistance received from } \\
\text { External Agency }\end{array}$ & 35 & 70.83 \\
\hline Having farmer-to-farmer extension & 81 & 29.17 \\
\hline No farmer-to-farmer extension & 39 & 67.5 \\
\hline
\end{tabular}


Fig.1 Locale of the study (oval shape indicate the selected blocks)

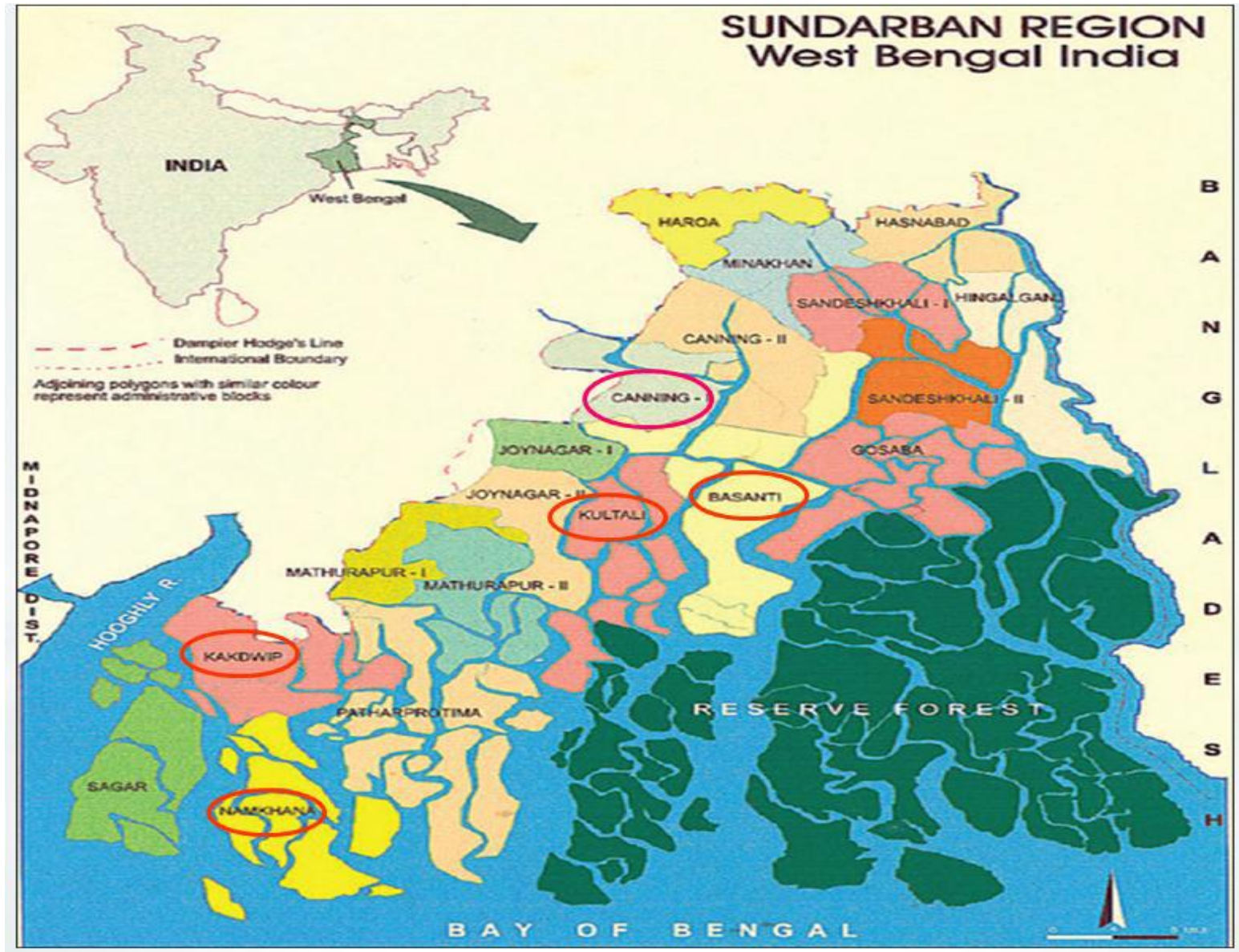

Fig.2 Different sources of annual Income of the farmers of Indian Sundarbans

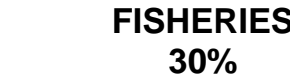

CROPS

$54 \%$

LIVESTOCK

$16 \%$ 
Fig.3 Different Credit Sources accessed by the farmers of Indian Sundarbans

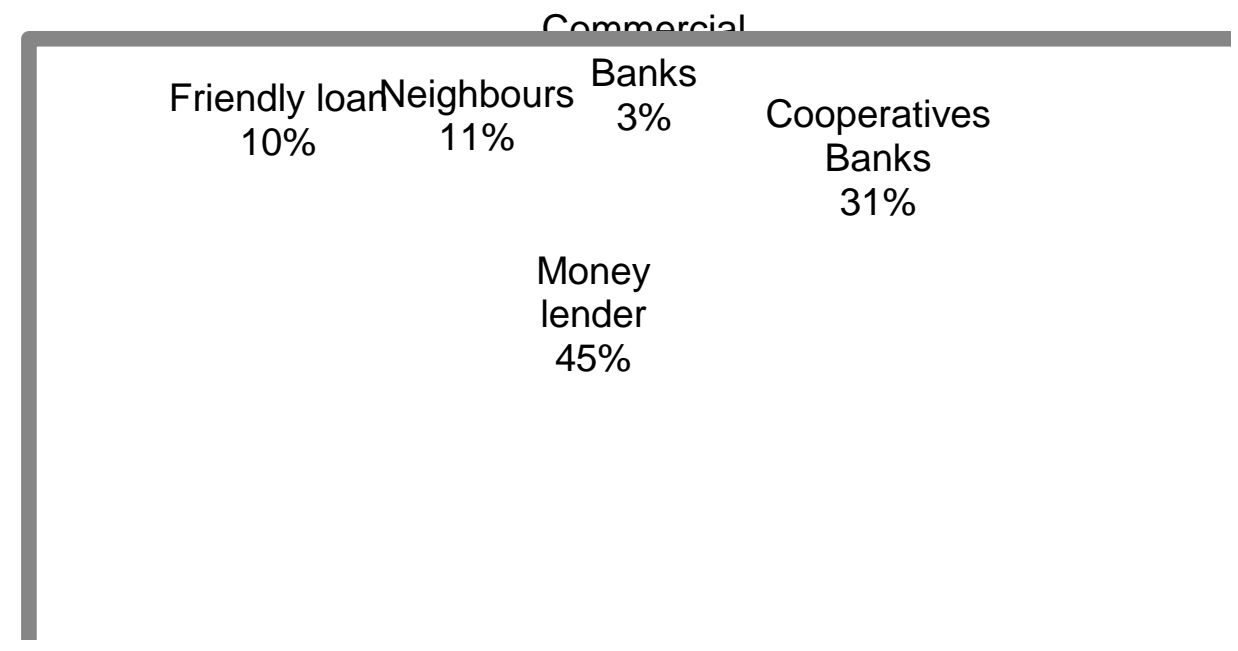

Fig.4 Respondents experienced different types of climatic events

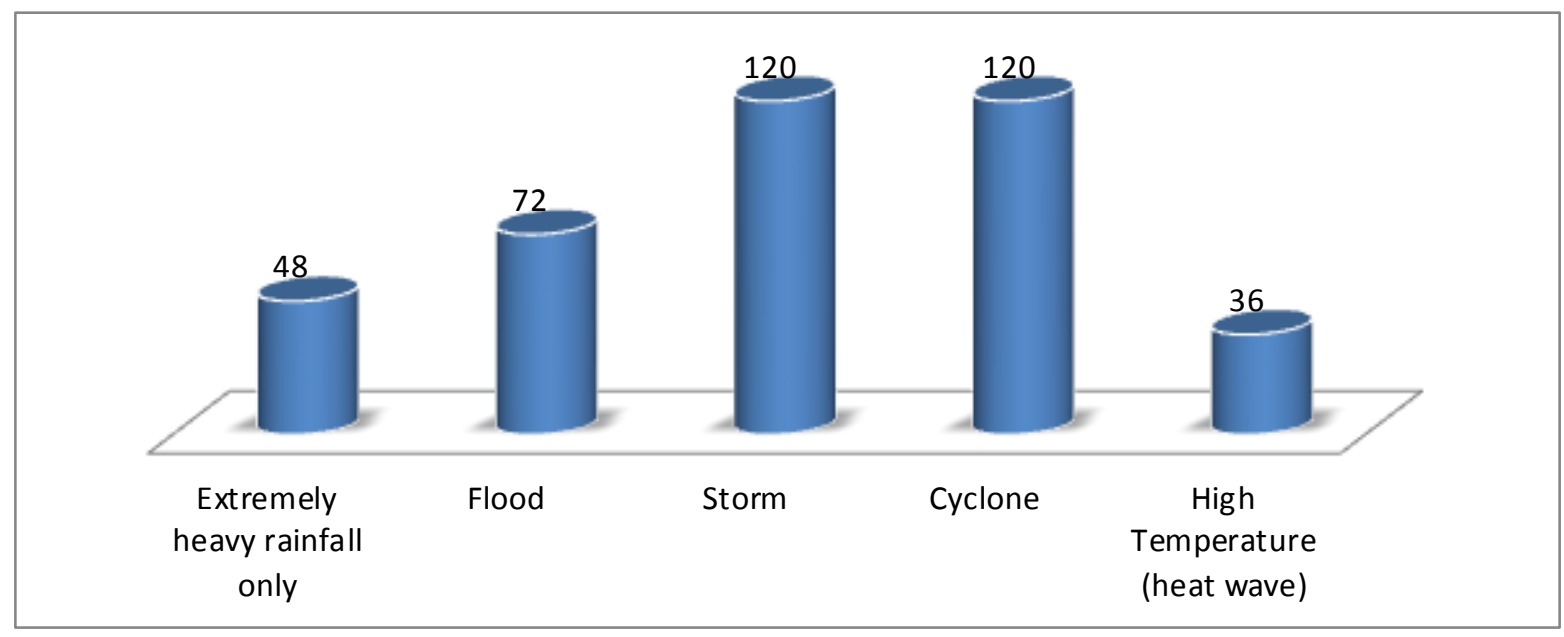

All the farmers involved in growing of crops as well as the rearing of livestock and fish farming are aware regarding changing climatic scenario. This study has uphold the socio economic condition of the farmers based on the various resources they have like demographic, physical, financial, natural and social. The policy makers both at state and district level lack clarity and awareness about the local impacts of global climate change in coastal regions. They also overlook the highly dynamic coping systems of the climate sensitive farmers. Many a times it has been noticed that the local institutions, both formal and informal, have been largely unable to communicate their needs, demands and challenges to the formalized state institutions that determine policy for this archipelago. Thus, this study throws light upon the existing condition of the Indian Sundarbans farmers which is very fragile and need immense care. The policy makers should keep these socio economic status in mind while formulating any strategies for the farming community of the climate sensitive Indian Sunderbans. 


\section{Acknowledgement}

We express our sincere thanks to the Director, ICAR-National Dairy Research Institute, Karnal, India for providing necessary helps and guidance. Special thanks to Indian Council of Agricultural Research for funding through Junior Research Fellowship.

\section{References}

CSE 2012Living with changing climate: Impact, vulnerability and adaptation challenges in Indian Sundarbans, New Delhi: Centre for Science and Environment

Danda, A. A., Sriskanthan, G., Ghosh, A., Bandyopadhyay, J. and Hazra, S. 2011.Indian Sundarbans Delta: A Vision, New Delhi: World Wide Fund for Nature-India

Government of India (2011) Census 2011, http://www.censusindia.gov.in/2011common/census_2011.html (24 January 2018)

Government of West Bengal 2010.West Bengal State Action on Climate Change, Kolkata: Government of West Bengal

Hazra, S., Samanta, K., Mukhopadhyay, A. and Akhand, A. 2010.Temporal Change

Detection (2001-2008) Study of

Sundarban, Kolkata: School of

Oceanographic Studies, Jadavpur University

IPCC, 2013.The Physical Science Basis. Contribution of Working Group I to the Fifth Assessment Report of the Intergovernmental Panel on Climate Change 2013. [Stocker, T.F., D. Qin, G.K., Plattner, M., Tignor, S.K., Allen, J., Boschung, A. Nauels, Y., Xia, V. Bex and P.M. Midgley (eds.)]. Cambridge University Press, New York: $1535 . \quad$ doi: 10.1017/CBO9781107415324

IPCC, 2015. Sixth Assessment Report, Geneva: Intergovernmental Panel on Climate Change (IPCC), http://www.ipcc.ch (9 February 2018).

Pakrashi, H. 2016. Is There a Tomorrow? The Story of Survival of Sunderbans against Climate Change. In: Nautiyal, S., Schaldach, R., Raju, K., Kaechele, H., Pritchard, B., Rao, K. (eds) Climate Change Challenge (3C) and SocialEconomic-Ecological InterfaceBuilding. Environmental Science and Engineering. Springer, Cham.

\section{How to cite this article:}

Suchandra Dutta, Sanjit Maiti, Sanchita Garai, Mukesh Bhakat and Subhashis Mandal. 2019. Socio Economic Scenario of the Farming Community Living in Climate Sensitive Indian Sundarbans. Int.J.Curr.Microbiol.App.Sci. 8(02): 3156-3164.

doi: https://doi.org/10.20546/ijcmas.2019.802.369 